\title{
LIST OF MAPS, GENEALOGIES AND TABLES
}

\section{Maps}

1 The empire during the Salian period (the kingdoms of Germany, Italy and Burgundy)

page $\mathrm{xv}$

2 Places mentioned in the text (Germany and northern Burgundy) xvi

3 Places mentioned in the text (Italy and southern Burgundy) xvii

4. Places mentioned in the text (Byzantium and Palestine) xviii

\section{Genealogies}

1 Genealogy of the Salians, c. 936-1125

xix

After S. Weinfurter, The Salian century: main currents in an age of transition, trans. B. M. Bowlus (Philadelphia, 1999), pp. 184-6

2 Frutolf of Michelsberg's genealogy of the Ottonian dynasty

Tables

1 Outline of Frutolf of Michelsberg's Chronicle

2 Synchronous history in Frutolf of Michelsberg's Chronicle 
T. J. H. McCarthy - 9781526112866

Downloaded from manchesterhive.com at 04/26/2023 07:10:25AM 